\title{
KINERJA KEUANGAN DAN PENYALURAN DANA SOSIAL YANG BERLANDASKAN TRI HITA KARANA (THK) PADA LEMBAGA PERKREDITAN DESA
}

\author{
Ni Wayan Alit Erlina Wati \\ Universitas Hindu Indonesia, surel: aliterlina@unhi.ac.id
}

\begin{abstract}
Financial performance is the result of decisions based on an assessment of the company's capabilities, both in terms of liquidity, activity, solvency and profitability made by the company's management. The purpose of this study was to determine the effect of ROA, CAR, and CR on the distribution of social funds based on Tri Hita Karana.

This research was conducted at the Lembaga Perkreditan Desa, Desa Adat in Penatih village. The type of data used is quantitative from 2014-2016 in the form of a quarterly balance sheet, income statement, trial balance and social fund ledger. Data collection is done through documentation and observation. The analysis technique used is multiple linear regression.

The results found that Return on Assets (ROA), Capital Adequacy Ratio (CAR) and Current Ratio (CR) have a positive affect on the distribution of social funds based on Tri Hita Karana. This shows that the higher the profit generated, the better the financial performance of the LPD where most of the social funds channeled are related to parhyangan and pawongan.
\end{abstract}

Keywords: ROA, CAR, CR, Parhyangan, pawongan.

\section{PENDAHULUAN}

LPD di Bali merupakan lembaga keuangan desa yang dimiliki oleh Desa Adat. Integrasi LPD di dalam kehidupan dan hukum adat telah menjadi sebuah kerangka yang sangat kuat untuk mengembangkan ekonomi masyarakat.Lembaga ini sudah menerapkan aturan, norma dan nilai yang diyakini bersama. LPD tidak saja memerankan fungsinya sebagai lembaga keuangan yang melayani transaksi keuangan masyarakat desa tetapi telah menjadi solusi atas keterbatasan akses dana bagi masyarakat pedesaan yang nota bene merupakan kelompok masyarakat dengan kemampuan ekonomi terbatas dani tanggung jawab ekonomi dan sosial pada masyarakat desa.

Dalam Perda Provinsi Bali No. 4 Tahun 2012 Tentang Perubahan Kedua Atas Perda No.8 Tahun 2002 tentang LPD pada Pasal 22 ayat 1 menetapkan bahwa pembagian keuntungan bersih LPD pada akhir tahun pembukuan ditetapkan cadangan modal $60 \%$, 
dana pembangunan desa $20 \%$, jasa produksi $10 \%$, dana pemberdayaan $5 \%$ dan dana sosial $5 \%$.

Kinerja keuangan dipakai manajemen sebagai salah satu pedoman untuk mengelola sumber daya yang dipercayakan kepadanya dengan merefleksikan kinerja fundamental perusahaan yang akan diukur dengan menggunakan data dari laporan keuangan perusahaan dimasa lalu dan digunakan untuk memprediksi keuangan dimasa yang akan datang (Rahayu 2015). Kinerja keuangan pada perusahaan dapat dinilai dengan menggunakan Return on Assets (ROA), current ratio (CR) dan Capital Adequacy Ratio (CAR). Dalam kinerja keuangan penyaluran dana sosial dinilai mampu memberikan kepastian mengenai prospek perusahaan dimasa yang akan datang. Perusahaan yang dapat memberikan harapan yang baik menyebabkan perusahaan tersebut akan dinilai tinggi oleh masyarakat. Kinerja keuangan diartikan sebagai penentuan ukuran-ukuran tertentu yang dapat mengukur keberhasilan suatu perusahaan dalam menghasilkan laba.

Pengungkapan tanggung jawab sosial sangat penting bagi sebuah perusahaan/lembaga untuk membangun serta mempertahankan kontribusi perusahaan dari sisi ekonomi, sosial, dan politik. Tanggung jawab sosial menekankan bahwa perusahaan harus mengembangkan praktik bisnis yang etis dan berkesinambungan secara ekonomi, sosial dan lingkungan. Tujuan bisnis tidak hanya mencari laba (profit), tetapi juga mensejahterakan orang (people), dan menjamin keberlanjutan hidup planet ini (Wardhani, 2013).

Penelitian ini akan diadakan pada Lembaga Perkreditan Desa di Kelurahan Penatih yang terdiri dari empat Desa Adat meliputi Desa Adat Angabaya, Desa Adat Penatih, Desa Adat Saba dan Desa Adat Tambawu, dari empat desa adat yang ada tiga diantaranya sudah memiliki pasar desa. Hal ini dilandasi oleh prestasi yang diterima kelurahan Penatih di 
tahun 2017 diantaranya penghargaan sebagai desa wisata, mewakili provinsi Bali dalam lomba Desa dan Kelurahan Tingkat Regional II Jawa- Bali. Keberhasialn yang diperoleh kelurahan penatih ini sangat didukung oleh keberdayaan masyarakat dalam bidang administrasi, ekonomi, sosial dan lingkungan.

Penelitian ingin mengetahui Return on Assets (ROA), Capital Adequacy Ratio (CAR), Current Ratio (CR) berpengaruh terhadap penyaluran dana sosial yang berlandaskan Tri Hita Karana pada LPD Desa Adat di Kelurahan Penatih dengan hasil ini diharapkan dapat menjadi pertimbangan dan masukan dalam menentukan kebijakankebijakan pada program LPD Desa Adat di Kelurahan agar kinerja keuangan dapat ditimgkatkan dan penyaluran dana sosial dapat tepat guna dan tepat sasaran untuk sebesarbesarnya kesejahteraan masyarakat Desa Adat berlandaskan Tri Hita Karana.

Gordha dalam Damayanthi (2011) menganalogkan ketiga filosofi Tri Hita Karana sebagai sumber daya (resources) untuk mewujudkan hidup, yakni kebahagiaan di bumi (Jagathita) dan kedamaian abadi di akhirat (Moksa). Menurutnya keyakinan hidup Hindu terwujudnya tujuan merupakan energi ketiga sumber daya, yaitu sumber daya ilahi (Brahman), sumber daya manusia (Praja), dan sumber daya alam (Kamadhuk).

Filosofi Tri Hita Karana diharapkan dapat membangun keharmonisan masyarakat yang hidup di Bali berlandaskan keseimbangan. Untuk menjadi tujuan THK yang diharapkan maka masyarakat sebaiknya memiliki kultur dan religi yang kuat dalam kehidupannya. Menurut Windia dan dewi (2007), saat ini di Bali filosofi Tri Hita Karana sudah diterapkan oleh sebagaian besar masyarakat di Bali bahkan bukan hanya yang beragama Hindu, melainkan yang non Hindu pun telah menerapkan filosofi THK. Fiosofi THK juga sangat relevan dengan aktivitas usaha/bisnis. 
Kinerja keuangan merupakan hasil keputusan berdasarkan penilaian terhadap kemampuan perusahaan, baik dari aspek likuiditas, aktivitas, solvabilitas dan profitabilitas yang dibuat oleh pihak-pihak yang berkepentingan terhadap perusahaan. Januarti dan Apriyanti (2005) dalam Rahayu (2015) menyatakan bahwa pengukuran kinerja keuangan atau prestasi operasi perusahaan dapat dilakukan dengan penilaian analisis rasio keuangan.. Pengukuran kinerja (performing meansurement) adalah kualifikasi atau efisiensi perusahaan merupakan keefektifan dalam pengoperasian bisnis selama periode akuntansi. Dengan demikian pengertian kinerja adalah suatu usaha formal yang dilaksanakan perusahaan untuk mengevaluasi efisien dan efektivitas dari aktivitas perusahaan yang telah dilaksanakan pada periode waktu tertentu. Hal ini sangat penting agar sumber daya digunakan secara optimal dalam menghadapi perubahan lingkungan Munawir (2000:31).

Untuk mengetahui prestasi dan posisi keuangan suatu perusahaan, seorang analisis keuangan memerlukan ukuran tertentu. Ukuran yang sering kali digunakan adalah rasio atau indeks yang menunjukkan hubungan antara dua data keuangan Dewi (2010). Bagi Lembaga Perkreditan Desa (LPD), kinerja keuangan merupakan salah satu faktor yang sangat penting dalam rangka pengembangan usaha yang sehat dan dapat menampung resiko kemungkinan kerugian. Apabila kinerja keuangan LPD baik, diharapkan dapat meningkatkan pertumbuhan LPD untuk jangka panjang. Sumber modal LPD juga berasal dari swadaya masyarakat sendiri atau urunan krama Desa, bantuan Pemerintah, tabungan nasabah/masyarakat, simpanan berjangka dan pinjaman dari lembaga-lembaga keuangan. Dengan modal tersebut LPD memberikan pinjaman kepada masyarakat/nasabah untuk kegiatan-kegiatan yang bersifat produktif pada sektor pertanian, industri, kerajinan kecil, perdagangan dan usaha-usaha lain yang dipandang perlu. 
LPD di Bali sudah didirikan sejak tahun 1984. Pencetus tiada lain, Gubernur Bali, Prof. Dr. Ida Bagus Mantra. Mula pertama, dibuat pilot project satu LPD di tiap-tiap Kabupaten. Kala itu, dasar hukum pembentukan LPD hanyalah Surat Keputusan (SK) Gubernur Kepala Daerah Tingkat I Bali No. 972 tahun 1984, tanggal 19 Nopember 1984. Namun, LPD secara resmi beroperasi mulai 1 Maret 1985. Hingga Tahun 2017 ini jumlah LPD di Bali dari masing-masing Kabupaten/Kota ataupun Kecamatan sudah tercatat sebanyak 1.422 LPD (lpd-bali.com). LPD merupakan badan usaha keuangan milik desa yang melaksanakan kegiatan usaha di lingkungan desa dan krama desa. Modal LPD salah satunya berasal dari swadaya masyarakat atau urunan krama desa. LPD juga merupakan wadah kekayaan desa adat yang dimiliki oleh warga adat. Lapangan usaha LPD adalah menghimpun dana krama desa dalam bentuk tabungan dan deposito, untuk memenuh tujuan tersebut maka LPD seharusnya terus meningkatkan kinerjanya agar tetap menjadi lembaga desa yang terpercaya.

Dalam rangka mewujudkan misinya, manajemen LPD harus dapat melakukan aktivitas operasionalnya dengan baik. Hal ini dapat dilakukan antara lain dengan menciptakan suatu struktur pengendalian intern yang memadai. Secara fungsi dan tujuan LPD adalah untuk memberikan kesempatan berusaha bagi para warga desa setempat, kemudian untuk menampung tenaga kerja yang ada di pedesaan, serta melancarkan lalu lintas pembayaran, sekaligus menghapuskan keberadaan lintah darat (rentenir). Keanggotaan LPD dari pemerintah sebagai krama desa adat secara struktural, terdiri dari berbagai banjar. Semua krama banjar yang ada di lingkungan desa, secara otomatis merupakan penopang dari keberadaan LPD.

Sesuai dengan Peraturan Daerah Provinsi Bali Nomor 4, Tahun 2012 tentang perubahan kedua atas Perda No. 8 Tahun 2002 tentang LPD pada Pasal 22 Ayat 1 
menentukan bahwa pembagian keuntungan bersih LPD pada akhir tahun pembukuan ditetapkan sebagai berikut : (a) cadangan modal 60\%, (b) dana pembangunan desa $20 \%$, (c) jasa produksi 10\%, (d) dana pemberdayaan 5\%, (e) dana sosial 5\%. Laporan tanggung jawab sosial ini tidak hanya bermanfaat bagi lembaga, tetapi juga bermanfaat bagi masyarakat desa adat. Laporan tanggung jawab sosial LPD dapat menunjukkan peran LPD bagi masyarakat khususnya desa adat tempat berdirinya LPD.

Tanggung jawab sosial adalah Komitmen untuk meningkatkan kesejahteraan masyarakat melalui praktik bisnis. Namun itu bukan amal tetapi itu adalah strategi bisnis inti dari sebuah organisasi. Tanggung jawab sosial perusahaan (Corporate Social Responsibility) merupakan salah satu dari beberapa tanggung jawab perusahaan kepada para pemangku kepentingan (stakeholder) yaitu orang atau kelompok yang dapat mempengaruhi atau dapat dipengaruhi oleh berbagai keputusan, kebijakan, maupun operasi perusahaan. Pemangku kepentingan akan memberikan dukungan terhadap operasi perusahaan apabila mereka memperoleh imbalan dari perusahaan yang sebanding atau lebih besar dibandingkan dengan kontribusi yang mereka berikan kepada perusahaan. Indonesia sebagai Negara yang terdiri dari berbagai perpaduan kebudayaan dan lingkungan, menyadari pentingnya untuk menjaga lingkungan khususnya bagi perusahaan yang kegiatannya berkaitan erat dengan lingkungan.

Prinsip Tri Hita Karana merupakan filosofi yang diajarkan di dalan Bhagawadgita, yaitu mengajarkan tetang tiga hal pokok kepada manusia untuk mencapai kebahagiaan tertinggi yaitu dharma/kebenaran Tuhan dan hakekat manusia, meningkatkan keyakinan hati akan kebenaran Tuhan, dan bagaimana berbuat di dalam kebenaran Tuhan (Palguna, 2007). Ketiga hubungan antara komponen Tri Hita Karana berkaitan erat antara yang satu dengan yang lainnya, hubungan antara manusia dengan Tuhan Yang Maha Esa 
(Parhyangan), yakni melaksanakan berbagai upacara keagamaan. Hubungan antara manusia dengan manusia (Pawongan atau Bhuana Alit), yakni dengan melakukan koordinasi/hubungan dengan organisasi atau masyarakat sekitarnya. Hubungan antara manusia dengan alam (Palemahan atau Bhuana), yakni memberikan arahan bagaimana manusia mengelola dan memanfaatkan sumberdaya alam yang terbatas yang terdiri atas tanah atau lahan pertanian, air irigasi, tanaman dan hewan agar dapat memberikan kesejahteraan bagi seluruh anggota masyarakat.

Parhyangan berasal dari kata Hyang yang berarti Hyang Widhi atau Tuhan Yang Maha Esa. Parhyangan merupakan salah satu dimensi dari filosofi THK yang menekankan bahwa kesejahteraan dicapai bila terealisasi hubungan harmonis antara manusia dengan Tuhan penciptanya. Kegiatan bisnis adalah sebuah persembahan yang tidak luput dari kontrol Tuhan (Surpha, 2001; Wiana, 2004; Ashrama, 2005; Windia dan `Dewi, 2007; dalam Damayanthi, 2011).

Parhyangan pada LPD dapat diimplementasikan dalam seberapa besar kontribusi LPD pada kegiatan ritual keagamaan, renovasi pura, kesejahteraan pemangku, bantuan untuk masyarakat yang kurang mampu dalam melaksanakan ritual keagamaan.

Pawongan berasal dari kata wong (orang atau penduduk) dalam masyarakat. Implementasi filosofi $T H K$ adalah melalui hubungan harmonis antar sesama manusia (Surpha, 2001; Wiana, 2004; Ashrama, 2005; dalam Dhamayanthi, 2011). Dalam konteks bisnis berupa hubungan antar karyawan dan hubungan lembaga dengan masyarakat. Implementasi pawongan pada LPD adalah berapa persen karyawan LPD berasal dari masyarakat tempat berdirinya LPD, keikutsertaan LPD pada program penanggulangan kemiskinan, dan lain-lain. 
Palemahan berasal dari kata lemah yang berarti tanah, tanah pekarangan atau wilayah pemukiman. Secara umum filosofi $T H K$, palemahan merupakan dimensi yang berhubungan dengan aspek fisik dari lingkungan di sekitar kita atau perusahaan. Di Bali palemahan berhubungan dengan tata letak perusahaan dan bangunan yang hendaknya disesuaikan dengan keyakinan agama dan kultur tempat perusahaan berada (Surpha, 2001; Wiana, 2004; Ashrama, 2005; dalam Damayanthi, 2011). Pada penelitian ini pertanggungjawaban sosial LPD berdasarkan filosofi palemahan dihubugkan dengan berapa besar kontribusi LPD terhadap aspek fisik di lingkungan sekitar LPD.

Tri Hita Karana digambarkan analog dengan sistem kebudayaan, maka semua subsistemnya terlihat saling berkaitan dan ada pengaruh lingkungan pada sistem tersebut. Pengalaman manusia Bali beradaptasi dengan lingkunganya dapat memunculkan salah satu elemen dari kebudayaan Bali yang disebut Tri Hita Karana. Esensi pemahaman tentang THK bahwa tujuan dari THK adalah untuk mencapai kebahagiaan hidup melalui proses harmoni dan kebersamaan (Windia dan Dewi, 2011). Tingkat profitabilitas yang tinggi pada perusahaan akan meningkatkan tingkat keuntungan yang tinggi dan menandakan pertumbuhan perusahaan dimasa yang akan datang. Semakin tinggi laba yang dihasilkan perusahaan maka semakin baik kinerja keuangan perusahaan tersebut (Hamzah. 2007).

\section{H1 : Return on Assets (ROA) berpengaruh positif terhadap penyaluran dana sosial yang berlandaskan Tri Hita Karana}

CAR merupakan rasio yang memperhitungkan seberapa jauh seluruh aktiva bank yang mengandung resiko (kredit, penyertaan, surat berharga, tagihan pada bank lain) ikut dibiayai dari dana modal sendiri. Tingginya rasio CAR dapat melindungi nasabah, sehingga dapat meningkatkan kepercayaan nasabah terhadap bank. Dengan semakin 
banyaknya kepercayaan nasabah terhadap perusahaan tersebut maka semakin baik kinerja keuangan yang dihasilkan (Hamzah. 2007).

H2 : Capital Adequacy Ratio (CAR) berpengaruh positif terhadap penyaluran dana sosial yang berlandaskan Tri Hita Karana

CR merupakan rasio untuk mengukur kemampuan perusahaan dalam membayar kewajiban jangka pendek atau utang yang segera jatuh tempo pada saat ditagih secara keseluruhan. Current ratio dapat pula dikatakan sebagai bentuk untuk mengukur tingkat keamanan (margin of safety) suatu perusahaan. Semakin baik tingkat keamanan yang diberikan maka semakin baik kinerja keuangannya.(Kasmir, 2012).

\section{H3 : Current Ratio (CR) berpengaruh positif terhadap penyaluran dana sosial yang berlandaskan Tri Hita Karana}

\section{METODE PENELITIAN}

Penelitian pada seluruh LPD yang ada di wilayah Kelurahan Penatih. Obyek penelitian ini adalah laporan keuangan Penatih yang terdiri dari laporan laba rugi dan neraca dari tahun 2014 -2016, serta buku pembantu dari dana sosial. Selain itu dilaksanakan wawancara dengan Kepala LPD Desa Adat, staff bidang pembukuan. Variabel penelitian adalah Kinerja Keuangan yaitu ROA, CAR dan CR. Selain itu terdapat variabel Dana Sosial Berlandaskan Tri Hita Karana (THK).

Indikator dari penyaluran dana sosial adalah biaya yang berkaitan dengan parhyangan, pawongan dan palemahan seperti biaya-biaya upacara, biaya lingkungan, biaya karyawan, biaya komunitas masyarakat.Return on Assets (ROA) dalam persentase, rumus perhitungan adalah : laba bersih dibagi total aktiva. Capital Adequacy Ratio (CAR) dalam persentase, rumus perhitungan yang digunakan adalah : modal yaitu modal inti dan modal pelengkap dibagi dengan ATMR. Dalam hal ini juga LPD Desa Adat di Kelurahan 
Penatih menghitung prosentase resiko ATMR yang dicadangkan pada kas (0\%), tabungan dan deposito (20\%), kredit (100\%) dan aktiva tetapo (100\%). Current Ratio (CR) dalam persentase, rumus perhitungan yang digunakan adalah : aktiva lancar dibagi dengan hutang lancar.

Penelitian ini akan diuji menggunakan metode regresi linear berganda untuk mengetahui pengaruh variabel-variabel yang terkait dalam penelitian. Di dalam model regresi, bukan variabel independen saja yang mempengaruhi variabel dependen, melainkan masih ada faktor lain yang dapat menyebabkan kesalahan dalam observasi, yaitu yang disebut kesalahan pengganggu $(\epsilon)$ atau disturbance's error. Metode regresi berganda akan dapat dijadikan alat estimasi yang tidak biasa jika telah memenuhi persyaratan Best Linear Unbiased Estimation (BLUE). Agar model analisis regresi yang dipakai dalam penelitian ini secara teoritis menghasilkan nilai parametik yang salah terlebih dahulu akan dilakukan pengujian asumsi klasik regresi yang meliputi uji normalitas, multikolinearitas, autokorelasi, dan heteroskedastisitas.

Untuk menguji hipotesis dalam penelitian ini digunakan, Uji parsial (Uji statistik t), Uji kelayakan model (Uji statistik F), Metode regresi linier berganda, dan koefisien determinasi,Ghozali (2005), uji stastistik t. Pengujian dilakukan dengan menggunakan significance level $0,05(\alpha=5 \%)$. Penerimaan atau penolakan hipotesis dilakukan dengan kriteria sebagai berikut : Jika nilai signifikan $>0,05$ maka hipotesis ditolak berarti secara parsial variabel independen tersebut tidak mempunyai pengaruh yang signifikan terhadap variabel dependen. Jika nilai signifikan $\leq 0,05$ maka hipotesis diterima, berarti secara parsial variabel independen tersebut mempunyai pengaruh yang signifikan terhadap variabel dependen. Uji Kelayakan Model (Uji Statistik F) dengan menggunakan signifikansi $5 \%$ 
Metode regresi linear berganda, adalah sebagai berikut :

$$
\mathbf{Y}=\mathbf{a}+\mathbf{b}_{1} \mathbf{X}_{1}+\mathbf{b}_{2} \mathbf{X}_{2}+\mathbf{b}_{3} \mathbf{X}_{3}+\mathbf{e}
$$

Keterangan :

$\mathrm{Y}=$ = Penyaluran Dana Sosial Berlandaskan Tri Hita Karana

$\mathrm{X}_{1} \quad=$ Return on Assets (ROA)

$\mathrm{X}_{2} \quad=$ Capital Adequacy Ratio (CAR)

$\mathrm{X}_{3} \quad=$ Current Ratio $(\mathrm{CR})$

a $\quad=$ konstanta

$\mathrm{b}_{1}, \mathrm{~b}_{2}, \mathrm{~b}_{3}, \quad=$ Koefisien regresi

e $\quad=$ Variabel penganggu (residual error)

Data dalam penelitian ini akan diolah dengan menggunakan program Statistical Package for Social Sciences (SPSS).

\section{HASIL DAN PEMBAHASAN}

Pada uji asumsi klasik mendapatkan hasil data berdistribusi normal dg nilai nilai Asymp.Sig.(2-tailed) 0,075 di atas 0,05, Uji Heteroskedasitas dianalisis melalui uji gletser dengan melihat tingkat signifikansi dengan tingkat signifikansi berada di atas 0,05 maka model regresi ini bebas dari masalah heteroskedasitas, uji multikolinearitasmenunjukkan bahwa tidak ada variabel bebas yang nilai tolerance kurang dari 0,1 atau VIF lebih dari 10,serta tidak terjadi autokorelasi. Kelayakan model dengan signifikansi 0,000 $<0,05$ dan model layak digunakan.

Uji $\mathrm{t}$ dan analisis regresi linear berganda ini digunakan tingkat signifikansi $\alpha=5 \%$ dapat dilihat pada tabel berikut:

Coefficients $^{\mathrm{a}}$

\begin{tabular}{|c|c|c|c|c|c|c|}
\hline \multirow{2}{*}{\multicolumn{2}{|c|}{ Model }} & \multicolumn{2}{|c|}{$\begin{array}{c}\text { Unstandardized } \\
\text { Coefficients } \\
\end{array}$} & \multirow{2}{*}{$\begin{array}{c}\text { Standardized } \\
\text { Coefficients } \\
\text { Beta }\end{array}$} & \multirow[b]{2}{*}{$\mathrm{t}$} & \multirow[b]{2}{*}{ Sig. } \\
\hline & & $\mathrm{B}$ & Std. Error & & & \\
\hline \multirow[t]{3}{*}{1} & (Constant) & $-6,723$ & 3,533 & & $-1,903$ &, 064 \\
\hline & ROA &, 1428 & ,286 &, 525 & 4,987 &, 000 \\
\hline & CAR &, 350 & , 168 & ,380 & 2,083 &, 043 \\
\hline
\end{tabular}




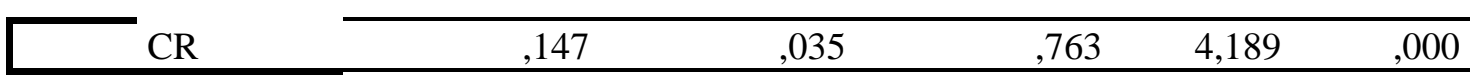

a. Dependent Variable: Penyaluran Dana Sosial

\section{Sumber: data diolah}

. Pengaruh ROA terhadap penyaluran dana sosial pada LPD Desa Adat di Kelurahan Penatih diperoleh nilai beta 1,428, t hitung 4,987 dan signifikansi sebesar $0,000<0,05$, maka disimpulkan $\mathrm{H}_{1}$ diterima, artinya ROA berpengaruh positif terhadap penyaluran dana sosial artinyadengan semakin meningkatnya ROA yang dihasilkan maka penyaluran dana sosial yang dilakukan LPD akan meningkat pula

Pengaruh CAR terhadap penyaluran dana sosial pada LPD Desa Adat Kelurahan Penatih nilai beta 0,350, thitung 2,083 dan signifikansi sebesar $0,043<0,05$ maka disimpulkan $\mathrm{H}_{2}$ diterima, artinya CAR berpengaruh positif terhadap penyaluran dana sosial artinya dengan meningkatnya CAR akan meningkat juga penyaluran dana sosialnya.

Pengaruh Current Ratio (CR) terhadap penyaluran dana sosial pada LPD Desa Adat di Kelurahan Penatih diperoleh nilai beta 0,147, t hitung 4,189 dan signifikansi sebesar $0,000<0,05$ maka disimpulkan $\mathrm{H}_{3}$ diterima, artinya $\mathrm{CR}$ berpengaruh positif terhadap penyaluran dana sosial artinya dengan meningkatnya CR maka penyaluran dana sosial yang dilakukan LPD di Kelurahan Penatih akan meningkat juga.

Pencapaian ROA terendah dari LPD Desa Adat Anggabaya sebesar 0,60 di tahun 2016 pada triwulan ke tiga, berarti masih rendahnya laba yang dapat dihasilkan oleh LPD Desa Adat Anggabaya dibandingkan dengan jumlah asset yang dikelola LPD ini, karena manajemen kredit belum mendukung dan lingkup penyaluran kredit masih terbatas pada wilayah yang sempit yaitu didukung oleh banjar Anggabaya saja. Pencapaian ROA tertinggi dicapai oleh LPD Desa Adat Penatih Puri sebesar 2,73\% di tahun 2014 pada triwulan pertama, walaupun dari segi asset yang dikelola LPD Desa Adat Penatih Puri paling rendah yaitu 2 sampai 3 milran ditahun 2014 sampai tahun 2016. Namun secara keseluruhan laba yang dihasilkan oleh LPD di Kelurahan Penatih meningkat dari tahun 2014 sampai tahun 2016 sehingga dana sosial yang berlandasakan THK yang disalurkan oleh LPD di Kelurahan Penatih juga meningkat.

Capital Adequacy Ratio (CAR) digunakan untuk mengukur kecukupan modal guna menutupi kemungkinan kegagalan dalam pemberian kredit. Dalam hasil uji statistik menyatakan CAR berpengaruh positif terhadap penyaluran dana sosial. Dengan modal yang dimiliki yaitu berupa modal inti dan modal pelengkap diharapkan LPD Desa Adat di Kelurahan Penatih memiliki dana cukup apabila suatu saat terjadi kegagalan dalam 
pemberian kredit. Nilai CAR minimal yang harus dimiliki adalah 30, tapi LPD Desa Adat Anggabaya dan Penatih selalu memiliki CAR dibawah 30, berarti resiko yang ditanggung dalam mengantisipasi dari kegagalan kredit yang disalurkan lebih tinggi dari LPD lainnya yang berada di Kelurahan Penatih. Nilai CAR terendah yaitu LPD desa Adat Anggabaya sebesar 16,98 di tahun 2014, sedangkan nilai CAR tertinggi yaitu LPD Desa Adat Penatih Puri sebesar 51,21 pada triwulan ke 4 di tahun 2015.

Penyaluran dana sosial berlandaskan Tri Hita Karana yang disalurkan LPD Desa Adat di Kelurahan Penatih adalah sebagian besar disalurkandi tingkat tingkat Parhayangan untuk kegiatan-kegiatan seperti Upacara-upacara Keagamaan yang berhubungan dengan Ida Sang Hyang Widhi Wasa/Tuhan Yang Maha Esa (Parhyangan), seperti penyaluran dana sosial untuk rangkaian upacara penyepian pada masing-masing banjar, penyaluran untuk biaya odalan di pura kahyangan tiga maupun pura lainnya, sumbangan perbaikan pura, melaksanakan tirtayatra bagi karyawan LPD dan prajuru adat.

Pada tingkat pawongan yang merupak hubungan manusia dengan sesama, penyaluran dana sosial dilakukan seperti memberikan sumbangan sembako pada masyarakat, pembinaan tabuh anak-anak maupun dewasa, sumbangan kupon bazar, sumbangan upacara pernikahan, potong gigi, sumbangan untuk upacara pitra yadnya, dan sumbangan atau santunan bagi masyarakat dan juga pegawai LPD Desa Adat di kelurahan Penatih baik sakit ataupun meninggal.

Pada tingkat Palemahan berkaitan dengan alam lingkungan penyaluran dana sosial yang dilakukan seperti memberikan sumbangan untuk perbaikan gambelan, perbaikan saluran air, sumbangan untuk pemberantasan sarang nyamuk. Penyaluran dana sosial untuk bidang ini masih sangat kurang dibandingkan dengan bidang lainnya.

\section{SIMPULAN}

Berdasarkan hasil analisis dan uraian dapat diperoleh simpulan Return On Assets (ROA) berpengaruh positif terhadap penyaluran dana sosial yang berlandaskan Tri Hita Karana pada LPD Desa Adat di Kelurahan Penatih, berarti semakin naik ROA yang mampu dihasilkan oleh LPD maka dana sosial yang akan disalurkan juga akan meningkat. Capital Adequacy Ratio (CAR) berpengaruh positif terhadap penyaluran dana social yang berlandaskan Tri Hita Karana pada LPD Desa Adat di Kelurahan Penatih, berartri dengan meningkatnya CAR maka akan diikuti dengan meningkatnya dana sosial yang akan 
disalurkan. Current Ratio (CR) berpengaruh positif terhadap penyaluran dana sosial yang berlandaskan Tri Hita Karana pada LPD Desa Adat di kelurahan Penatih , berari semakin meningkatnya nilai CR maka akan diikuti dengan meningkatnya dana sosial yang akan disalurkan oleh LPD Desa Adat di kelurahan Penatih

Saran-saran yaitu sebagai yaitu Bagi LPD Desa Adat di Kelurahan penatih, terutama LPD Anggabaya agar dapat meningkatkan kinerja keuangannya karena nilai ROA dan CAR serta CR masih terlalu rendah dari yang diharapkan.Bagi penelitian selanjutnya sebaiknya dapat meneliti selain pengaruh kinerja keuangan, seperti apa saja yang dapat mempengaruhi besarnya dana sosial yang disalurkan dalam parhyangan, pawongan dan palemahan. Agar dapat meningkatkan sumber daya manusia (SDM) karyawan dan masyarakat, LPD diharapkan dapat memberikan beasiswa pendidikan sebagai bagian dari penyaluran dana sosialnya. 


\section{DAFTAR PUSTAKA}

Ang Swat Lin Lindawati, Marsella Eka Puspita, (2015), ISSN: 2086-7603. Corporate Social Responsibility: Implikasi Stakeholder dan Legitimacy GAP dalam Peningkatan Kinerja Perusahaan. Universitas Ma Chung Malang.

Ayu Oktyas Putri, Journal Vol. 4 No. 4 (2015). Pengaruh Kinerja Keuangan terhadap Nilai Perusahaan dengan Pengungkapan CSR sebagai Variabel Pemoderasi. Sekolah Tinggi Ilmu Ekonomi Indonesia.

Ardhi Hamzah, Journal 2007. Analisis Rasio Likuiditas, Profitabilitas, Aktivitas, Solvabilitas dan Investment Opportunity Set dalam Tahapan Siklus Kehidupan Perusahaan Manufaktur yang Terdaftar di Bursa Efek Jakarta (BEJ) Tahun $2001-2005$.

Bramantya Adhi Cahya, 2010. Analisis Pengaruh Kinerja Keuangan terhadap Tanggung Jawab Sosial Perusahaan (Corporate Social Responsibility) Studi Kasus di Indonesia Periode Tahun 2007 - 2008. Universitas Diponegoro Semarang.

Ernia Christy Rahayu, Journal Vol. 4 No. 3 (2015). Dampak Kinerja Keuangan dan Pengungkapan Corporate Social Responsibility Terhadap Nilai Perusahaan. Sekolah Tinggi Ilmu Ekonomi Indonesia (STIESIA) Surabaya.

Ghozali, Imam. 2005. Aplikasi Analisis Multivariat dengan Program SPSS, Edisi ketiga. Semarang: Badan Penerbit Universitas Diponegoro.

Gusti Ayu Rosiana, Gede Juliarsa, Maria M. Ratna Sari, (2013), ISSN: 23028556. Pengaruh Pengungkapan CSR terhadap Nilai Perusahaan dengan Profitabilitas sebagai Variabel Pemoderasi. Universitas Udayana.

I.G.A. Eka Damayanthi, Vol. 6 No. 2 (2011). Pengungkapan Tanggung Jawab Sosial Lembaga Perkreditan Desa (LPD) Berdasarkan Filosofi Tri Hita Karana. Universitas Udayana.

Kasmir, 2012. Analisis Laporan Keuangan. Edisi 1-8. Jakarta. PT Raja Frafindo Persada.

Kurnianto, Eko Addy. 2011. Pengaruh Corporate Social Responsibility terhdap Kinerja Keuangan Perusahaan "Studi Empiris pada Perusahaan Perbankan yang Terdaftar di Bursa Efek Indonesia Tahun 2005-2008". Skripsi. Fakultas Ekonomi Universitas Diponegoro, Semarang.Made Rusmala Dewi, (2010), ISSN: 1410-4628. Pengaruh Kinerja Keuangan terhadap Pertumbuhan Aset LPD Kecamatan Denpasar Utara. Universitas Udayana. 
Munawir. (2000). Analisa laporan keuangan. Edisi ke empat. Jogjakarta: liberty.

Palguna, A.A.B. 2007. Budaya Tri Hita Karana dan Trikaya Parisudha, Denpasar: Wahana.

Peraturan Daerah Provinsi Bali Nomor 4 Tahun 2012 Tentang Lembaga Perkreditan Desa.

Rulyanti Susi Wardhani, (2013), ISSN: 1412-5366. Pengaruh CSR Disclosure terhadap Nilai Perusahaan dengan Kinerja Keuangan sebagai Variabel Intervening (Studi Kasus Perusahaan Manufaktur yang Terdaftar di BEI). Universitas Bangka Belitung.

Standar Akuntansi Keuangan (SAK ETAP), 2009. Ikatan Akuntan Indonesia. Jakarta.

Sugiyono, 2008. Metode Penelitian Manajemen. Penerbit Alfabeta Bandung.

Sugiyono, 2013. Metode Penelitian Manajemen. Penerbit Alfabeta Bandung.

Sutedja, M. 2012. Tri Hita Karana And World Peace: Bali Hinduism Philoshopy Of Life. Surabaya: Paramita.

Totok Mardikanto. 2014. Corporate Social Responsibility Bandung: Alfabeta.

Undang-undang Republik Indonesia No. 4o Tahun 2007 Tentang Perseroan Terbatas.

Undang-undang Republik Indonesia No. 25 Tahun 2007 Tentang Penanaman Modal.

Windia, W. dan Dewi. 2011. Analisis Bisnis Berlandaskan Tri Hita Karana. Denpasar: Udayana University Press.

Wirawan, I Md A.2011. Tri Hita Karana: Kajian Teologi, Sosiologi dan Ekologi Menurut Veda, Surabaya: Paramita. 